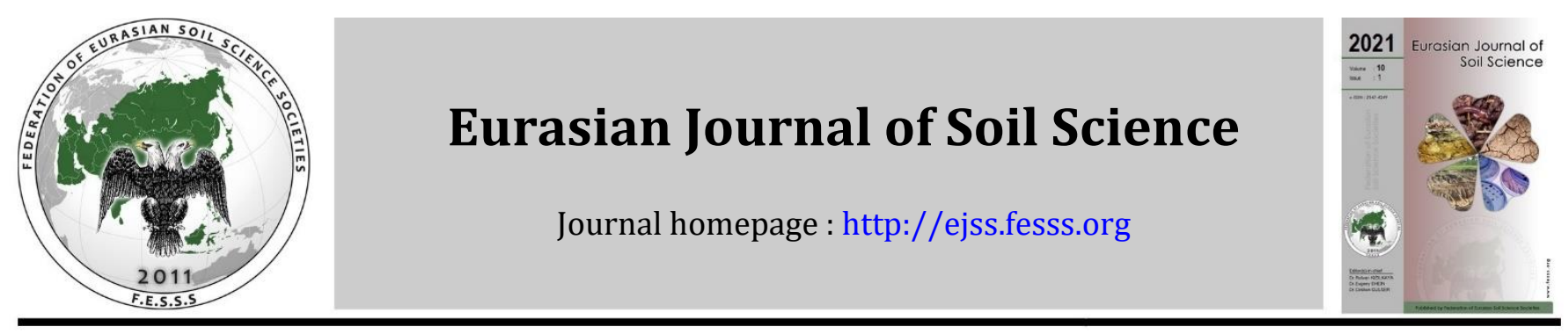

\title{
Performance of vermicompost in zinc and boron nutrition for quality production of cabbage
}

\section{Md. Mosharaf Hossain Sarker *, Md. Abul Kashem}

Department of Soil Science, Sylhet Agricultural University, Sylhet-3100, Bangladesh

\section{Article Info}

Received : 24.02 .2020

Accepted : 05.01.2021

Available online : 12.01 .2021

Author(s)
M.M.H.Sarker *
M.A. Kashem
* Corresponding author

\begin{abstract}
The quality and efficacy of vermicompost are greatly influenced by the respective feeding materials as well as earthworm species used in vermicomposting. Consequently, the variable role of applied vermicompost is reflected in crop production. With a view to observe the efficacy of vermicompost produced from various sources in supplementing zinc and boron requirement for quality production of cabbage, a field study was conducted in Floodplain soil of Bangladesh. Six treatment combinations comprising of vermicompost from different sources, and different levels of zinc and boron from mineral fertilizers were tested in the study. The vermicompost used in different treatments were produced from different combinations of feeding materials (cowdung and poultry litter) and earthworm species (Eisenia fetida and Eudrilus eugeniae). A control treatment having no supplement of $\mathrm{Zn}$ and B was tested in the study. Higher measurements were recorded for most of the parameters studied, i.e., head diameter, marketable yield and total yield in the vermicompost treated plots than the solely mineral fertilizer treated plot. Except for $\mathrm{P}$, the highest uptake of each of the elements by cabbage was observed due to the application of $\mathrm{T}_{3}$ treatment (VC-ECD @2.0 $\mathrm{t} \mathrm{ha}^{-1}+1.5 \mathrm{~kg} \mathrm{Zn}$ $\mathrm{ha}^{-1}+1.0 \mathrm{~kg} \mathrm{~B} \mathrm{ha}^{-1}$ ). The findings of this research work indicate the additional benefit of using vermicompost over the mineral fertilizer in supplying zinc and boron for better production of cabbage.
\end{abstract}

Keywords: Vermicompost, performance, zinc, boron, quality, cabbage.

(C) 2021 Federation of Eurasian Soil Science Societies. All rights reserved

\section{Introduction}

Producing food for an ever-increasing population from limited land resources is one of the big challenges in Bangladesh. To cope up with the situation, the arable land is being intensively used in the recent previous years. Hence, there is an increasing trend of cropping intensity in this country and it was 171 and $194.28 \%$ in the year 1983-84 and 2015-16, respectively (BBS, 2017). Consequently, the soil resource of this country has been impacted negatively and deficiency of different nutrients diagnosed one after another. Micronutrients like $\mathrm{Zn}$ and B deficiency along with macronutrient deficiency (N, P, K, and S) have already emerged in soils of the country (Islam, 2008).

In Bangladesh, it is a common practice to use urea in over-dose while other fertilizers like TSP, MoP, and gypsum in sub-optimal doses. The use of micronutrient-containing fertilizers is very rare in crop cultivation. This unbalanced management of fertilizers is hampering the successful production of crops (Rijpma and Jahiruddin, 2004). Usually, a very small amount of micronutrient than macronutrient is required in crop production; but micronutrient deficiency can make a plant unable to complete its life cycle. Again, excessive application of micronutrients may create phytotoxicity as well as threaten food safety. The toxic and deficient status of boron in soil and plant is very close to each other (Reisenauer et al., 1973). Deviation in proper doses of

https://doi.org/10.18393/ejss.859136

http://ejss.fesss.org/10.18393/ejss.859136
P目Publisher e-ISSN : 2147-4249 
micronutrients might hamper crop growth and quality also. Different mineral fertilizer sources are commonly used in the country to meet up the requirement of micronutrients as organic sources are very limited there. In such a situation application of vermicompost can be an excellent option to address the problem.

Vermicompost is one of the highly nutritive manures as well as a potential growth promoter in crop cultivation. It has ten times higher nutritive value for a plant than farmyard manure (Lourduraj and Yadav, 2005). Prabakaran (2005) reported the considerable content of vitamins, hormones, enzymes and different plant nutrients in vermicompost. Theunissen et al. (2010) reported higher content of micronutrients namely iron, copper, zinc, and manganese in vermicompost. Increased content of $\mathrm{Zn}$ along with other micronutrients was showed in vermicompost applied soil than the control plot (Abdelmonem et al., 2016). The nutrient content of vermicompost greatly depends on the feeding materials and species of earthworm used in vermicomposting. The growth as well as performance of earthworms, was impacted a lot by the palatability and nutrient content of various organic materials used in vermicomposting (Suthar, 2007). The growth of earthworm in specific organic substrate is determined by the palatability as well as suitability to eat by worms (Yadav and Garg, 2011). Rajendran and Thivyatharsan (2014) found the highest content of different macronutrients (N, P, and $\mathrm{K}$ ) and organic carbon in vermicompost produced by using E. eugeniae among four different earthworm species. Such variations among vermicompost produced from using different earthworm species were also reported by Singh et al. (2014).

Different micronutrients have specific role in cabbage production. Among the micronutrients, zinc and boron are more important than others due to their availability in soil, mobility in soil-plant system, especially in the case of cole crops. Zinc deficiency in soil was reported in the early 1990s. From the nutritional point of view, different reports suggested that about one-fourth of the total world's population is threatened by Zn deficiency (Maret and Standstead, 2006). Improving Zn status in food crops through various means may be one of the options to mitigate the problem. For addressing this issue, many scientists planned different strategies including $\mathrm{Zn}$ fertilization in crop production through mineral sources as well as from various organic fertilizers (Yilmaz et al., 1997; Cakmak et al., 1998; Khattak et al., 2006; Maqsood et al., 2009). Light-textured acid soils and soils having low organic matter are usually deficient in boron (Keren and Bingham, 1985; Mandal et al., 2004). Boron deficiency has been diagnosed for various field crops in different countries throughout the world (Shorrocks, 1997).

Among the thirty agro-ecological zones (AEZs) of Bangladesh, the Surma-Kushiyara Floodplain (AEZ 20) is an important one formed on sediments of the rivers graining into the Meghna catchment area from the hills. The soils of this area are featured with low to medium organic matter content where zinc content is medium and boron content is low to medium (BARC, 2012). Considering above-mentioned points, a study was conducted to evaluate the response of cabbage to zinc and boron application through both vermicomposts as well as chemical fertilizers in Surma-Kushiyara Floodplain soil.

\section{Material and Methods}

\section{Experimental location}

Field study, as well as chemical analysis of soil-plant samples in the laboratory, was included in the study. Farmer's field in Sunamgonj sadar upazila under Sunamgonj district was selected to conduct the field experiment. Duration of the field experimentation was November/2018 to January/2019. The experimental plot lies under the Eastern Surma-Kushiyara Floodplain (AEZ 20) (FAO and UNDP, 1988). The analytical part of the study was performed in the laboratory located in the Department of Soil Science (Sylhet Agricultural University) as well as the Sylhet regional soil laboratory of SRDI (Soil Resource Development Institute).

\section{Collection, preparation and analysis of soil samples}

At the very beginning of field experimentation, the soil sample (at $0-15 \mathrm{~cm}$ depth) from the research plot was collected and processed as per standard methods. Different basic soil properties and some macro- and micronutrients were analyzed from the processed soil sample following standard methodology as described in Table 1. The analytical results of this initial soil are presented in Table 2.

\section{Crop variety, treatments, and design used}

A widely cultivated popular hybrid variety of cabbage, Atlas 70 was used in the experiment. Six treatment combinations were tested in the experiment which are given below-

$\mathrm{T}_{1:}$ Control

$\mathrm{T}_{2}: 3 \mathrm{~kg} \mathrm{Zn} \mathrm{ha}^{-1}+2 \mathrm{~kg} \mathrm{~B} \mathrm{ha}^{-1}$

$\mathrm{T}_{3}$ : VC-ECD@2.0 $\mathrm{tha}^{-1}+1.5 \mathrm{~kg} \mathrm{Zn} \mathrm{ha}^{-1}+1.0 \mathrm{~kg} \mathrm{~B} \mathrm{ha}^{-1}$

$\mathrm{T}_{4}$ : VC-EuCD@2.0 $\mathrm{t} \mathrm{ha}^{-1}+1.5 \mathrm{~kg} \mathrm{Zn} \mathrm{ha}^{-1}+1.0 \mathrm{~kg} \mathrm{~B} \mathrm{ha}^{-1}$

$\mathrm{T}_{5}$ : VC-ECDPL@2.0 tha $\mathrm{t}^{-1}+1.5 \mathrm{~kg} \mathrm{Zn} \mathrm{ha}^{-1}+1.0 \mathrm{~kg} \mathrm{~B} \mathrm{ha}^{-1}$

$\mathrm{T}_{6}$ : VC-EuCDPL@2.0 t ha-1 + $1.5 \mathrm{~kg} \mathrm{Zn} \mathrm{ha}^{-1}+1.0 \mathrm{~kg} \mathrm{~B} \mathrm{ha}^{-1}$ 
Table 1. Methods for analyses of soil properties

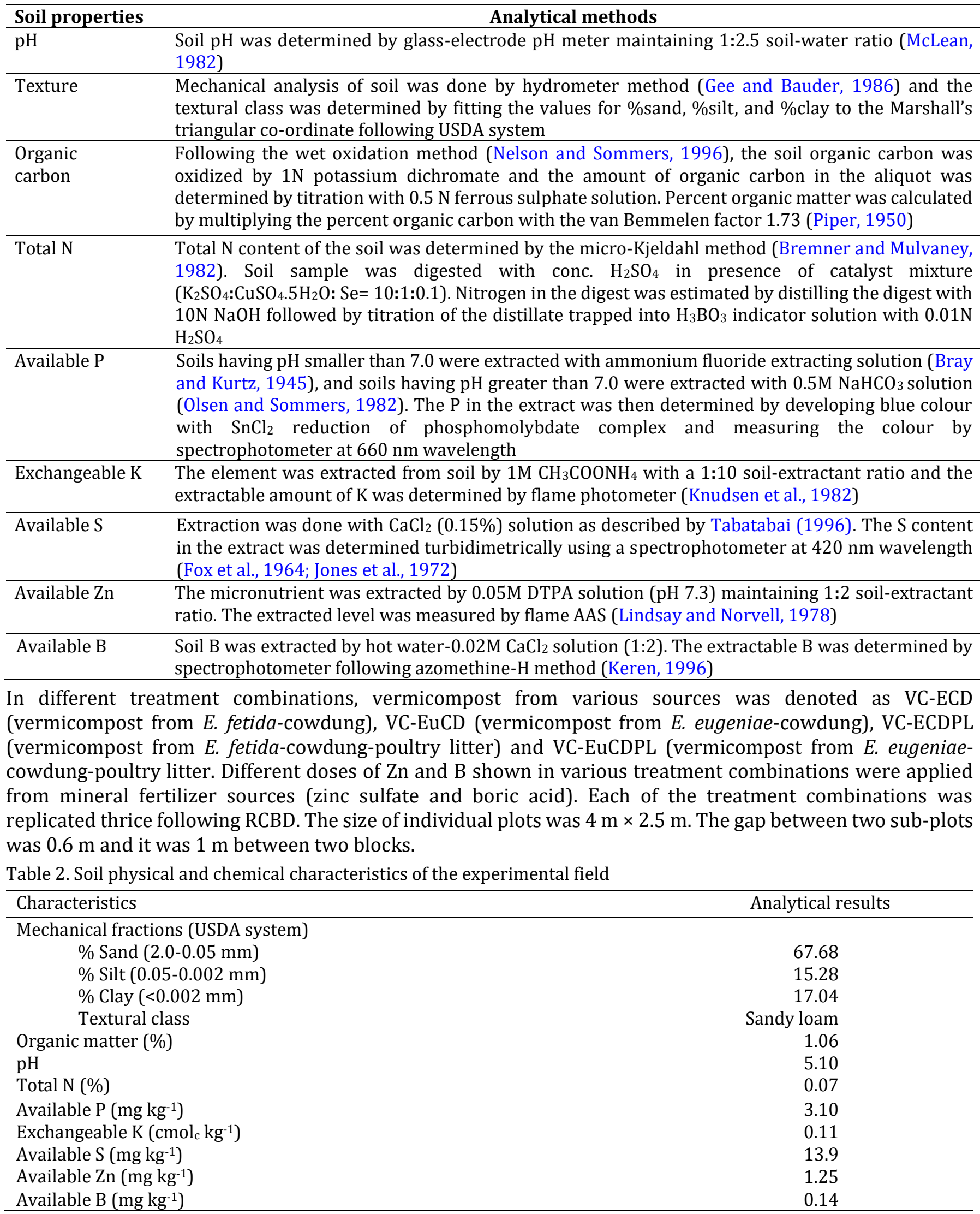

\section{Macronutrient doses and their application}

In the experiment, the soil was applied with different macronutrients (N, P, K, and S) through vermicompost as well as chemical fertilizers. Fertilizer Recommendation Guide was used to calculate the required amount of macronutrients other than the amount received from the applied vermicompost (BARC, 2012). The respective doses applied in the experiment are presented Table 3. Urea, triple super phosphate, muriate of potash, and 
gypsum were applied as inorganic sources of $\mathrm{N}, \mathrm{P}, \mathrm{K}$, and $\mathrm{S}$, respectively. The full amount of all recommended fertilizers and manures other than urea was mixed with the soil of experimental plots before transplanting cabbage seedling. At 10, 25 and 35 DAT (Days after transplanting) the recommended amount of urea was sidedressed in equal split doses.

Table 3. Application doses of different macronutrients

\begin{tabular}{lc}
\hline Macronutrients & Application doses \\
\hline Nitrogen & $130 \mathrm{~kg} \mathrm{ha}^{-1}$ \\
Phosphorus & $55 \mathrm{~kg} \mathrm{ha}^{-1}$ \\
Potassium & $85 \mathrm{~kg} \mathrm{ha}^{-1}$ \\
Sulphur & $25 \mathrm{~kg} \mathrm{ha}^{-1}$ \\
\hline
\end{tabular}

\section{Intercultural operations}

Various intercultural activities were performed during the experimentation to achieve better growth and performance of cabbage. Immediate after the transplantation, banana leaf sheath was used at day time to protect the tender cabbage seedlings from direct scorching sunlight. Besides, the seedlings were watered two times (morning and evening) in a day for three days after transplanting. Other intercultural operations like irrigation and pesticide application were performed as per requirement.

\section{Data collection}

At the proper edible stage, cabbage head yield was recorded by harvesting an area of $4 \mathrm{~m}^{2}$ in each of the subplots. Head yield was recorded by weighing the immediately harvested heads. Data on different growth and yield contributing characters as well as yield were collected from five pre-selected cabbage plants. Such plants were selected randomly from the sub-plots excluding the area to be harvested for yield data.

\section{Collection, preparation and nutrient analysis of cabbage samples}

Samples of cabbage head including stem were collected while harvesting head for yield data. After air drying those samples were cut off into finer parts and placed into an electric oven at $65^{\circ} \mathrm{C}$. This oven drying process was continued for about twenty-four hours and then the well-dried crispy plant materials ground finely using a plant grinder. Thus ground samples were analyzed chemically to determine the nutrient $(\mathrm{N}, \mathrm{P}, \mathrm{K}, \mathrm{S}, \mathrm{Zn}$, and B) content using standard protocols as described in Table 4. Uptakes of different nutrient elements were determined using respective nutrient concentration data and yield of cabbage.

Table 4. Methods used for plant analysis

\begin{tabular}{cl}
\hline Elements & Analytical methods \\
\hline $\mathrm{N}$ & The micro-Kjeldahl method (Bremner and Mulvaney, 1982) was followed. \\
\hline $\mathrm{P}$ & $\begin{array}{l}\text { Colorimetric method: The concentration of P was determined colorimetrically using molybdovanadate } \\
\text { solution (Yoshida et al., 1976). }\end{array}$ \\
\hline $\mathrm{K}$ & The concentration of Kin the digest was determined directly by a flame photometer (Yoshida et al., 1976). \\
\hline $\mathrm{S}$ & $\begin{array}{l}\text { Turbidimetric method: The S concentration in the digest was determined by developing turbid using } \\
\mathrm{BaCl}_{2} \text { (Chapman and Pratt, 1961). }\end{array}$ \\
\hline $\mathrm{Zn}$ & $\begin{array}{l}\text { The concentration of Zn in the digest was determined directly by an atomic absorption } \\
\text { spectrophotometer (Yoshida et al., 1976). }\end{array}$ \\
\hline $\mathrm{B}$ & $\begin{array}{l}\text { The B concentration in the digest in terms of color was determined by a spectrophotometer following the } \\
\text { azomethine-H method (Keren, 1996). }\end{array}$
\end{tabular}

\section{Statistical analysis of data}

A computer-based statistical package software $\mathrm{R}$ was used for the analysis of collected data. Different standard statistical methodologies were followed to determine the significant effects of the treatments. The treatment mean separation was adjudged by Duncan's Multiple Range Test (Gomez and Gomez, 1984).

\section{Results}

\section{Effects on growth parameters of cabbage Plant height at harvest}

Cabbage plant heights at different DAT were not significantly affected by the treatments applied and it was ranged from 11.13 to $11.64,20.46$ to 22.69 , and 27.33 to $32.11 \mathrm{~cm}$ at $20 \mathrm{DAT}, 40 \mathrm{DAT}$, and at harvest, respectively (Table 5).

\section{Number of loose leaves plant ${ }^{-1}$ at harvest}

Like plant height, the number of loose leaves plant- 1 was also varied non-significantly by the treatments used (Table 5). In $\mathrm{T}_{4}$ treatment, the number of loose leaves was the highest where in $\mathrm{T}_{2}$ treatment it was the lowest. 
Table 5. Effects of sources of vermicompost on growth parameters of cabbage

\begin{tabular}{|c|c|c|c|c|c|c|}
\hline \multirow[t]{2}{*}{ Treatment } & \multicolumn{3}{|c|}{$\begin{array}{l}\text { Plant height at different } \\
\text { growth stage }(\mathrm{cm})\end{array}$} & \multirow{2}{*}{$\begin{array}{c}\text { No. of loose } \\
\text { leaves at } \\
\text { harvest (No) }\end{array}$} & \multirow{2}{*}{$\begin{array}{l}\text { Length of } \\
\text { the } \\
\text { largest } \\
\text { leaf }(\mathrm{cm})\end{array}$} & \multirow{2}{*}{$\begin{array}{l}\text { Breadth } \\
\text { of the } \\
\text { largest } \\
\text { leaf }(\mathrm{cm})\end{array}$} \\
\hline & $\begin{array}{l}\text { At } 20 \\
\text { DAT }\end{array}$ & $\begin{array}{l}\text { At } 40 \\
\text { DAT }\end{array}$ & $\begin{array}{c}\text { At } \\
\text { harvest }\end{array}$ & & & \\
\hline $\mathrm{T}_{1:}$ Control & 11.15 & 20.46 & 27.33 & 17.14 & $32.00 \mathrm{~b}$ & $27.50 \mathrm{~b}$ \\
\hline $\mathrm{T}_{2}: 3 \mathrm{~kg} \mathrm{Zn} \mathrm{ha}^{-1}+2 \mathrm{~kg} \mathrm{~B} \mathrm{ha}^{-1}$ & 11.13 & 21.93 & 30.33 & 16.93 & $34.67 \mathrm{ab}$ & $34.75 a$ \\
\hline $\mathrm{T}_{3}:$ VC-ECD@2.0 t ha-1 + 1.5 kg Zn ha-1 + $1.0 \mathrm{~kg} \mathrm{~B} \mathrm{ha}^{-1}$ & 11.60 & 22.69 & 32.11 & 16.30 & $38.67 \mathrm{a}$ & $36.67 \mathrm{a}$ \\
\hline $\mathrm{T}_{4}:$ VC-EuCD@2.0 t ha-1 + 1.5 kg Zn ha-1 + $1.0 \mathrm{~kg} \mathrm{~B} \mathrm{ha}^{-1}$ & 11.64 & 21.06 & 30.44 & 16.61 & $36.67 \mathrm{a}$ & $35.33 a$ \\
\hline T5: VC-ECDPL@2.0 t ha-1 + $1.5 \mathrm{~kg} \mathrm{Zn} \mathrm{ha}^{-1}+1.0 \mathrm{~kg} \mathrm{~B} \mathrm{ha}^{-1}$ & 11.28 & 21.73 & 31.11 & 17.44 & $35.00 \mathrm{ab}$ & $35.50 \mathrm{a}$ \\
\hline T6: VC-EuCDPL@2.0 t ha-1 + 1.5 kg Zn ha-1 + $1.0 \mathrm{~kg} \mathrm{~B} \mathrm{ha}^{-1}$ & 11.52 & 22.13 & 32.00 & 16.40 & $38.08 \mathrm{a}$ & $36.33 a$ \\
\hline $\mathrm{CV}(\%)$ & 4.93 & 3.70 & 7.57 & 3.47 & 6.47 & 9.06 \\
\hline Significance level & NS & NS & NS & NS & 0.05 & 0.05 \\
\hline
\end{tabular}

Means followed by the same letter in a column are not significantly different at $5 \%$ level by DMRT

$\mathrm{CV}=\mathrm{Co}$-efficient of variation

VC-ECD = Vermicompost produced from cowdung using Eisenia fetida earthworm species

$\mathrm{VC}-\mathrm{EuCD}=$ Vermicompost produced from cowdung using Eudrilus eugeniae earthworm species

VC-ECDPL= Vermicompost produced from cowdung + poultry litter using Eisenia fetida earthworm species

VC-EuCDPL= Vermicompost produced from cowdung + poultry litter using Eudrilus eugeniae earthworm species

\section{Length of the largest leaf}

The application of different treatments affected the length of the largest leaf significantly and it ranged from 32.00 to $38.67 \mathrm{~cm}$ (Table 5). The largest leaf was produced by $\mathrm{T}_{3}$ treatment and at par result was recorded in the remaining treatments other than $\mathrm{T}_{1}$. On the other hand, the shortest leaf was measured in $\mathrm{T}_{1}$ treatment and at par result also recorded in both $\mathrm{T}_{2}$ and $\mathrm{T}_{5}$ treatments.

\section{Breadth of the largest leaf}

Like the length of the largest leaf, the breadth of the largest leaf was also significantly differed by the treatments where the broadest leaf $(36.67 \mathrm{~cm})$ was produced in $\mathrm{T}_{3}$ treatment and it was at par with that of all other treatments except the control treatment (Table 5). The narrowest leaf $(27.50 \mathrm{~cm})$ was resulted from the control treatment where no $\mathrm{Zn}$ and B were applied.

\section{Effects on yield contributing parameter and yield of cabbage}

The parameters included head diameter, marketable head yield, and gross yield.

\section{Head diameter}

The head diameter of cabbage varied significantly by different treatments of the study (Table 6). The largest diameter $(24.70 \mathrm{~cm})$ was produced in the T3 treatment and it had statistical similarity with that of remaining treatments other than T1 and T2. Again, the lowest diameter $(22.57 \mathrm{~cm})$ was recorded in the control treatment and it was statistically similar to that of $\mathrm{T} 2$ and T4 treatments.

\section{Marketable head yield}

Significant differences were observed in the marketable head yield of cabbage produced by different treatments and it ranged from 33.71 to $51.71 \mathrm{t} \mathrm{ha}^{-1}$ (Table 6). Marketable yield was the highest for $\mathrm{T}_{3}$ treatment and it had statistical similarity with the remaining treatments other than $\mathrm{T}_{2}$ and the control. The lowest yield was produced by the $\mathrm{T}_{1}$ treatment and it had statistical similarities with the yield of the $\mathrm{T}_{2}$ treatment $(40.16 \mathrm{t}$

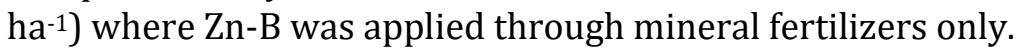

\section{Gross yield}

The application of different treatments affected the gross yield of cabbage significantly where it varied from 51.71 to $63.36 \mathrm{t} \mathrm{ha}^{-1}$ (Table 6). The highest gross yield producing treatment was $\mathrm{T}_{3}$ and at par result was found for all other treatments except the control. The $\mathrm{T}_{2}$ treatment produced gross head yield (57.74 $\left.\mathrm{t} \mathrm{ha}^{-1}\right)$ which was higher than that of the T1 treatment; whereas it was lower than the gross yield of all other treatments.

\section{Effects on nutrient uptake by cabbage}

The concentration of various nutrients (N, P, K, S, Zn, and B) in cabbage samples as presented in Table 7 was estimated as fresh weight basis. The nutrient uptake which was calculated based on nutrient concentration and yield data has shown in Table 8. 
Table 6. Effects of sources of vermicompost on yield and yield contributing characters of cabbage

\begin{tabular}{|c|c|c|c|}
\hline Treatment & $\begin{array}{l}\text { Head diameter } \\
(\mathrm{cm})\end{array}$ & $\begin{array}{c}\text { Marketable } \\
\text { head yield }\left(\mathrm{t} \mathrm{ha}^{-1}\right)\end{array}$ & $\begin{array}{c}\text { Total yield } \\
\left(\mathrm{t} \mathrm{ha}^{-1}\right)\end{array}$ \\
\hline $\mathrm{T}_{1:}$ Control & $22.57 \mathrm{c}$ & $33.77 \mathrm{c}$ & $51.71 \mathrm{c}$ \\
\hline $\mathrm{T}_{2}: 3 \mathrm{~kg} \mathrm{Zn} \mathrm{ha-1}+2 \mathrm{~kg} \mathrm{~B} \mathrm{ha}^{-1}$ & $23.55 b c$ & $40.16 \mathrm{bc}$ & $57.74 b$ \\
\hline $\mathrm{T}_{3}:$ VC-ECD@2.0 t ha-1 + 1.5 kg Zn ha-1 + 1.0 kg B ha-1 & $24.70 \mathrm{a}$ & $51.71 \mathrm{a}$ & $63.36 \mathrm{a}$ \\
\hline $\mathrm{T}_{4}:$ VC-EuCD@2.0 t ha-1 + 1.5 kg Zn ha-1 + $1.0 \mathrm{~kg} \mathrm{~B} \mathrm{ha}^{-1}$ & 23.66abc & $45.49 \mathrm{ab}$ & $58.71 \mathrm{ab}$ \\
\hline T5: VC-ECDPL@2.0 t ha-1 + 1.5 kg Zn ha-1 + 1.0 kg B ha-1 & $23.86 a b$ & $44.83 \mathrm{ab}$ & $58.74 \mathrm{ab}$ \\
\hline T6: VC-EuCDPL@2.0 t ha-1 + 1.5 kg Zn ha ${ }^{-1}+1.0 \mathrm{~kg} \mathrm{~B} \mathrm{ha}^{-1}$ & $24.12 \mathrm{ab}$ & $49.10 \mathrm{a}$ & $61.13 \mathrm{ab}$ \\
\hline $\mathrm{CV}(\%)$ & 2.58 & 9.20 & 5.17 \\
\hline Significance level & 0.05 & 0.01 & 0.05 \\
\hline
\end{tabular}

Means followed by the same letter in a column are not significantly different at 5\% level by DMRT

$\mathrm{CV}=\mathrm{Co}$-efficient of variation

VC-ECD= Vermicompost produced from cowdung using Eisenia fetida earthworm species

$\mathrm{VC}-\mathrm{EuCD}=$ Vermicompost produced from cowdung using Eudrilus eugeniae earthworm species

VC-ECDPL= Vermicompost produced from cowdung + poultry litter using Eisenia fetida earthworm species

VC-EuCDPL= Vermicompost produced from cowdung + poultry litter using Eudrilus eugeniae earthworm species

Table 7. Effects of sources of vermicompost on nutrient content of cabbage

\begin{tabular}{|c|c|c|c|c|c|c|}
\hline Treatments & $\begin{array}{c}\mathrm{N} \\
(\%)\end{array}$ & $\begin{array}{c}\mathrm{P} \\
(\%)\end{array}$ & $\begin{array}{c}\mathrm{K} \\
(\%)\end{array}$ & $\begin{array}{c}\mathrm{S} \\
(\%)\end{array}$ & $\begin{array}{c}\mathrm{Zn} \\
\left(\mu \mathrm{g} \mathrm{g}^{-1}\right)\end{array}$ & $\begin{array}{c}\mathrm{B} \\
\left(\mu \mathrm{g} \mathrm{g}^{-1}\right)\end{array}$ \\
\hline $\mathrm{T}_{1:}$ Control & 0.164 & 0.0219 & $0.121 b$ & 0.0243 & $6.05 c$ & $5.07 \mathrm{~b}$ \\
\hline $\mathrm{T}_{2}: 3 \mathrm{~kg} \mathrm{Zn} \mathrm{ha} \mathrm{k}^{-1}+2 \mathrm{~kg} \mathrm{~B} \mathrm{ha}{ }^{-1}$ & 0.174 & 0.0190 & $0.127 \mathrm{ab}$ & 0.0295 & $9.23 \mathrm{ab}$ & $7.87 \mathrm{a}$ \\
\hline $\mathrm{T}_{3}:$ VC-ECD@2.0 tha ${ }^{-1}+1.5 \mathrm{~kg} \mathrm{Zn} \mathrm{ha}^{-1}+1.0 \mathrm{~kg} \mathrm{~B} \mathrm{ha}^{-1}$ & 0.174 & 0.0191 & $0.139 a$ & 0.0303 & $9.62 \mathrm{a}$ & $8.92 \mathrm{a}$ \\
\hline $\mathrm{T}_{4}$ : VC-EuCD@2.0 tha-1 + $1.5 \mathrm{~kg} \mathrm{Zn} \mathrm{ha}^{-1}+1.0 \mathrm{~kg} \mathrm{~B} \mathrm{ha}^{-1}$ & 0.169 & 0.0197 & $0.141 \mathrm{a}$ & 0.0292 & $8.52 b$ & $8.45 a$ \\
\hline $\mathrm{T}_{5}:$ VC-ECDPL@2.0 t ha-1 + $1.5 \mathrm{~kg} \mathrm{Zn} \mathrm{ha}^{-1}+1.0 \mathrm{~kg} \mathrm{~B} \mathrm{ha}^{-1}$ & 0.171 & 0.0194 & $0.137 \mathrm{a}$ & 0.0280 & $8.65 \mathrm{ab}$ & $8.15 a$ \\
\hline $\mathrm{T}_{6}:$ VC-EuCDPL@2.0 t ha ${ }^{-1}+1.5 \mathrm{~kg} \mathrm{Zn} \mathrm{ha}^{-1}+1.0 \mathrm{~kg} \mathrm{~B} \mathrm{ha}^{-1}$ & 0.178 & 0.0200 & $0.141 \mathrm{a}$ & 0.0290 & $9.30 \mathrm{ab}$ & $8.55 a$ \\
\hline $\mathrm{CV}(\%)$ & 4.01 & 6.22 & 5.73 & 7.70 & 5.99 & 7.91 \\
\hline Significance level & NS & NS & 0.05 & NS & 0.001 & 0.001 \\
\hline
\end{tabular}

Note: Nutrient concentration of cabbage was expressed as fresh weight basis

Means followed by the same letter in a column are not significantly different at $5 \%$ level by DMRT

$\mathrm{CV}=\mathrm{Co}$-efficient of variation

VC-ECD = Vermicompost produced from cowdung using Eisenia fetida earthworm species

VC-EuCD= Vermicompost produced from cowdung using Eudrilus eugeniae earthworm species

VC-ECDPL= Vermicompost produced from cowdung + poultry litter using Eisenia fetida earthworm species

VC-EuCDPL= Vermicompost produced from cowdung + poultry litter using Eudrilus eugeniae earthworm species

\section{Nitrogen uptake}

Significant effect of different applied treatments on $\mathrm{N}$ uptake was observed. The $\mathrm{T}_{3}$ treatment helped for the highest uptake (110.05 $\left.\mathrm{kg} \mathrm{ha}^{-1}\right)$ of $\mathrm{N}$ which had statistical similarity with that of $\mathrm{T}_{2}, \mathrm{~T}_{5}$, and $\mathrm{T}_{6}$ treatments. The control treatment showed the lowest uptake of $\mathrm{N}$.

\section{Phosphorus uptake}

Non-significant effect of various treatments was noticed for P uptake by cabbage and it varied from 11.01 to $12.18 \mathrm{~kg} \mathrm{ha}^{-1}$. There was a higher $\mathrm{P}$ concentration in the control treatment than $\mathrm{T}_{2}$ treatment (Table 7) and consequently this situation contributed to estimate higher $\mathrm{P}$ uptake in the control than in the $\mathrm{T}_{2}$ treatment.

\section{Potassium uptake}

Significant influence of different treatments on $\mathrm{K}$ uptake by cabbage was recorded. The $\mathrm{T}_{3}$ treatment had induced the highest uptake (87.90 $\left.\mathrm{kg} \mathrm{ha}^{-1}\right)$ and at par results were observed for all vermicompost applied treatments. Potassium uptake was the lowest in $\mathrm{T}_{1}$ treatment.

\section{Sulphur uptake}

Significant variations were observed among the $S$ uptakes by cabbage in different treatments where it varied from 12.54 to $19.14 \mathrm{~kg} \mathrm{ha}^{-1}$. The lowest and the highest values of uptake were found in the control and $\mathrm{T}_{3}$ treatments, respectively.

\section{Zinc uptake}

Different treatments had significant effects on $\mathrm{Zn}$ uptake by cabbage. The $\mathrm{T}_{3}$ treatment had induced the highest uptake (609.42 $\mathrm{g} \mathrm{ha}^{-1}$ ) where the lowest uptake was calculated for control treatment. The $\mathrm{T}_{2}$ treatment which received no Zn and B containing mineral fertilizers had induced for $531.82 \mathrm{~kg} \mathrm{ha}^{-1} \mathrm{Zn}$ uptake. 
Table 8. Effects of sources of vermicompost on nutrient uptake by cabbage

\begin{tabular}{|c|c|c|c|c|c|c|}
\hline Treatments & $\begin{array}{c}\mathrm{N} \\
\text { uptake } \\
\left(\mathrm{kg} \mathrm{ha}^{-1}\right)\end{array}$ & $\begin{array}{c}\mathrm{P} \\
\text { uptake } \\
\left(\mathrm{kg} \mathrm{ha}^{-1}\right)\end{array}$ & $\begin{array}{c}\mathrm{K} \\
\text { uptake } \\
\left(\mathrm{kg} \mathrm{ha}^{-1}\right)\end{array}$ & $\begin{array}{c}\text { S } \\
\text { uptake } \\
\left(\mathrm{kg} \mathrm{ha}^{-1}\right)\end{array}$ & $\begin{array}{c}\mathrm{Zn} \\
\text { uptake } \\
\left(\mathrm{g} \mathrm{ha}^{-1}\right)\end{array}$ & $\begin{array}{c}\text { B } \\
\text { uptake } \\
\left(\mathrm{g} \mathrm{ha}^{-1}\right) \\
\end{array}$ \\
\hline $\mathrm{T}_{1}$ : Control & 0.164 & 0.0219 & $0.121 \mathrm{~b}$ & 0.0243 & $6.05 c$ & $5.07 \mathrm{~b}$ \\
\hline $\mathrm{T}_{2}: 3 \mathrm{~kg} \mathrm{Zn} \mathrm{ha} \mathrm{k}^{-1}+2 \mathrm{~kg} \mathrm{~B} \mathrm{ha}^{-1}$ & 0.174 & 0.0190 & $0.127 \mathrm{ab}$ & 0.0295 & $9.23 \mathrm{ab}$ & $7.87 \mathrm{a}$ \\
\hline $\mathrm{T}_{3}:$ VC-ECD@2.0 tha $\mathrm{t}^{-1}+1.5 \mathrm{~kg} \mathrm{Zn} \mathrm{ha}^{-1}+1.0 \mathrm{~kg} \mathrm{~B} \mathrm{ha}^{-1}$ & 0.174 & 0.0191 & $0.139 \mathrm{a}$ & 0.0303 & $9.62 \mathrm{a}$ & $8.92 \mathrm{a}$ \\
\hline $\mathrm{T}_{4}:$ VC-EuCD@2.0 tha-1 + 1.5 kg Zn ha-1 + $1.0 \mathrm{~kg} \mathrm{~B} \mathrm{ha}^{-1}$ & 0.169 & 0.0197 & $0.141 \mathrm{a}$ & 0.0292 & $8.52 b$ & $8.45 a$ \\
\hline $\mathrm{T}_{5}:$ VC-ECDPL@2.0 t ha-1 + $1.5 \mathrm{~kg} \mathrm{Zn} \mathrm{ha}^{-1}+1.0 \mathrm{~kg} \mathrm{~B} \mathrm{ha}^{-1}$ & 0.171 & 0.0194 & $0.137 \mathrm{a}$ & 0.0280 & $8.65 \mathrm{ab}$ & $8.15 \mathrm{a}$ \\
\hline T6: VC-EuCDPL@2.0 t ha ${ }^{-1}+1.5 \mathrm{~kg} \mathrm{Zn} \mathrm{ha}^{-1}+1.0 \mathrm{~kg} \mathrm{~B} \mathrm{ha}^{-1}$ & 0.178 & 0.0200 & $0.141 \mathrm{a}$ & 0.0290 & $9.30 \mathrm{ab}$ & $8.55 a$ \\
\hline CV $(\%)$ & 4.01 & 6.22 & 5.73 & 7.70 & 5.99 & 7.91 \\
\hline Significance level & NS & NS & 0.05 & NS & 0.001 & 0.001 \\
\hline
\end{tabular}

Means followed by the same letter in a column are not significantly different at $5 \%$ level by DMRT

$\mathrm{CV}=$ Co-efficient of variation

VC-ECD= Vermicompost produced from cowdung using Eisenia fetida earthworm species

VC-EuCD = Vermicompost produced from cowdung using Eudrilus eugeniae earthworm species

VC-ECDPL= Vermicompost produced from cowdung + poultry litter using Eisenia fetida earthworm species

VC-EuCDPL= Vermicompost produced from cowdung + poultry litter using Eudrilus eugeniae earthworm species

\section{Boron uptake}

Boron uptake by cabbage was varied significantly due to the effect of various treatments applied and it ranged from 262.61 to $565.04 \mathrm{~g} \mathrm{ha}^{-1}$. The highest and the lowest uptakes were found in $\mathrm{T}_{3}$ and $\mathrm{T}_{1}$ treatments, respectively. The highest uptake-inducing treatment $\left(\mathrm{T}_{3}\right)$ had statistical similarity with that of remaining all vermicompost applied treatments other than $\mathrm{T}_{5}$.

\section{Changes in soil properties after experimentation with cabbage}

Analytical results of different soil parameters and nutrient elements in the initial (before initiation of the experiment) and post-harvest soils (after 1-crop) have presented in Table 9. There were few changes in soil properties due to the application of different mineral fertilizers and vermicompost to supplement $\mathrm{Zn}$ and $\mathrm{B}$ for cabbage production.

Table 9. Changes in soil properties as influenced by different treatments applied in cabbage

\begin{tabular}{|c|c|c|c|c|c|c|c|c|}
\hline Treatment & $\mathrm{pH}$ & $\frac{\text { Org. C }}{(\%)}$ & Tot. N & $\begin{array}{c}\text { Ex. K } \\
\text { mol }_{\mathrm{c}} \mathrm{kg}\end{array}$ & Av. P & Av. S & $\frac{\text { Av.Zn }}{\left.\mathrm{mg} \mathrm{kg}^{-1}\right)}$ & Av. B \\
\hline Initial soil: & 5.1 & 1.06 & 0.072 & 0.110 & 3.1 & 13.90 & 1.25 & 0.136 \\
\hline \multicolumn{9}{|l|}{ Post-harvest soil: } \\
\hline $\mathrm{T}_{1:}$ Control & 4.9 & $1.11 b$ & $0.095 b$ & 0.173 & $8.31 \mathrm{a}$ & 14.97 & $1.26 \mathrm{c}$ & $0.150 c$ \\
\hline $\mathrm{T}_{2}: 3 \mathrm{~kg} \mathrm{Zn} \mathrm{ha}^{-1}+2 \mathrm{~kg} \mathrm{~B} \mathrm{ha}^{-1}$ & 4.9 & $1.09 \mathrm{~b}$ & $0.112 \mathrm{a}$ & 0.174 & $6.10 \mathrm{c}$ & 15.35 & $2.50 \mathrm{ab}$ & $0.280 \mathrm{~b}$ \\
\hline $\mathrm{T}_{3}:$ VC-ECD@2.0 t ha-1 + 1.5 kg Zn ha-1 + $1.0 \mathrm{~kg} \mathrm{~B} \mathrm{ha}^{-1}$ & 4.8 & $1.23 \mathrm{a}$ & $0.117 \mathrm{a}$ & 0.194 & $7.20 \mathrm{~b}$ & 17.42 & $2.60 \mathrm{a}$ & $0.313 \mathrm{ab}$ \\
\hline T4: VC-EuCD@2.0 t ha-1 + 1.5 kg Zn ha-1 + 1.0 kg B ha ${ }^{-1}$ & 4.7 & $1.23 a$ & $0.116 a$ & 0.180 & $6.97 \mathrm{bc}$ & 16.91 & $2.15 \mathrm{ab}$ & $0.300 \mathrm{ab}$ \\
\hline T5: VC-ECDPL@2.0 t ha-1 + $1.5 \mathrm{~kg} \mathrm{Zn} \mathrm{ha}^{-1}+1.0 \mathrm{~kg} \mathrm{~B} \mathrm{ha}^{-1}$ & 4.8 & 1.19ab & $0.120 \mathrm{a}$ & 0.180 & $7.02 \mathrm{bc}$ & 17.09 & $2.02 \mathrm{~b}$ & $0.310 \mathrm{ab}$ \\
\hline T6: VC-EuCDPL@2.0 t ha-1 + 1.5 kg Zn ha-1 +1.0 kg B ha-1 & 4.7 & $1.24 \mathrm{a}$ & $0.114 \mathrm{a}$ & 0.186 & $7.14 \mathrm{bc}$ & 17.23 & $2.32 \mathrm{ab}$ & $0.323 a$ \\
\hline $\mathrm{CV}(\%)$ & 2.49 & 3.14 & 4.83 & 6.00 & 7.53 & 6.17 & 12.64 & 7.24 \\
\hline Significance level & NS & 0.01 & 0.01 & NS & 0.05 & NS & 0.01 & 0.001 \\
\hline
\end{tabular}

Means followed by the same letter in a column are not significantly different at 5\% level by DMRT

CV: Co-efficient of variation

VC-ECD= Vermicompost produced from cowdung using Eisenia fetida earthworm species

VC-EuCD= Vermicompost produced from cowdung using Eudrilus eugeniae earthworm species

VC-ECDPL= Vermicompost produced from cowdung + poultry litter using Eisenia fetida earthworm species

VC-EuCDPL= Vermicompost produced from cowdung + poultry litter using Eudrilus eugeniae earthworm species

The decreased $\mathrm{pH}$ value was recorded in post-harvest soils than the initial soil. The values were nonsignificantly varied with the applied treatments. After completion of the experiment, the organic carbon content of the soil was found to be increased slightly and it varied from 1.11 to $1.24 \%$. The organic carbon content was found as the highest in the $\mathrm{T}_{6}$ treatment and it had statistical similarity with that of all other vermicompost receiving treatments. Like organic carbon, total $\mathrm{N}$ content in soil was higher in post-harvest soils over all the treatments, with the range of $0.095-0.120 \%$ (initial level $0.072 \%$ ). Available P content showed a remarkable increase in post-harvest soils than the initial content which ranged from 6.10 to 8.31 $\mathrm{mg} \mathrm{kg}^{-1}$ (initial status $3.1 \mathrm{mg} \mathrm{kg}^{-1}$ ). Significant differences were observed in soil $\mathrm{P}$ contents of different treatments where the highest and the lowest contents were in control and $\mathrm{T}_{2}$ treatments, respectively. Though increased content $\left(0.173-0.194 \mathrm{cmolc} \mathrm{kg}^{-1}\right)$ was found for exchangeable $\mathrm{K}$ level from the initial soil test value $\left(0.110 \mathrm{cmolc} \mathrm{kg}^{-1}\right)$, those were not significantly varied from each other. Like $\mathrm{K}$, the $\mathrm{S}$ level of post-harvest soils 
also non-significantly varied from 14.97 to $17.42 \mathrm{mg} \mathrm{kg}^{-1}$ where the initial status was $13.90 \mathrm{mg} \mathrm{kg}^{-1}$. The Zn content of soil increased considerably in Zn-treated plots, as expected due to $\mathrm{Zn}$ application but almost static in the control treatment. After 1-crop experimentation, the available Zn status of the soil varied from 1.26 to $2.60 \mathrm{mg} \mathrm{kg}^{-1}$ against the initial level of $1.25 \mathrm{mg} \mathrm{kg}^{-1}$. Similarly, higher content of B was found in post-harvest soils as compared to the initial content. Those contents have significantly differed from each other where the highest value $\left(0.323 \mathrm{mg} \mathrm{kg}^{-1}\right)$ was recorded for the soil of $\mathrm{T} 6$ treatment and the other vermicompost receiving treatments had at par results.

\section{Discussion}

All the yield parameters studied, i.e., head diameter, marketable yield, and total yield recorded in the vermicompost plus mineral fertilizer treated plots differed from those of solely mineral fertilizer treated plots as well as the control plot. This finding indicates the suitability of vermicompost comparing with the mineral fertilizer for yield components of cabbage.

Except for P, uptake of all the nutrients by cabbage was significantly differed by the treatments added. The highest value of uptake in each of the elements was observed due to the application of $\mathrm{T}_{3}$ treatment (VCECD@2.0 t ha-1 $+1.5 \mathrm{~kg} \mathrm{Zn} \mathrm{ha}^{-1}+1.0 \mathrm{~kg} \mathrm{~B} \mathrm{ha}^{-1}$ ). Such a result has agreed with the previous findings of other researches. The combined application of mineral fertilizers with vermicompost has induced the highest uptake of various nutrients (N, P, K, and Mg) by rice plant (Jadhav et al., 1997). Sreenivas et al. (2000) found an almost similar result in the case of $\mathrm{N}$ uptake by ridge gourd by applying a combination of inorganic fertilizer and vermicompost. Phosphorus uptake was found higher in the control treatment than all other treatments; it is because of the higher $\mathrm{P}$ concentration in $\mathrm{T}_{1}$ than the remaining treatments. The interaction effect between applied $\mathrm{P}$ and $\mathrm{Zn}$ might be responsible for reduced uptake of $\mathrm{P}$ in different treatments other than the control. Except for the control all other treatments received Zn either from mineral fertilizer or from both the mineral and organic source. Antagonistic interactions of $\mathrm{Zn}$ and $\mathrm{P}$ have been confirmed from numerous studies (Webb and Loneagan, 1988; Hu et al., 1996; Bukvic et al., 2003; Mousavi, 2011). There was the superiority of the vermicompost applied treatments in nutrient uptake issue for most of the elements. The high potentiality of vermicompost in supplying plant nutrients might be contributed to this. Vermicompost is rich in plant nutrients, vitamins, and hormones which consequently have impacted on better growth and performance of plants (Kale et al., 1992; Edwards, 1988; Makulec, 2002; Sinha et al., 2009). Due to larger particular surface area, vermicompost have the capability to provide huge micro-sites for microbial activity as well as for plant nutrient adsorption (Shi-wei and Fu-zhen, 1991).

From the analytical results of post-harvest soil and initial soil, it is found that the $\mathrm{pH}$ of vermicompost treated soils $\left(\mathrm{T}_{3}-\mathrm{T}_{6}\right)$ was found lower than the control treatment and even than the initial $\mathrm{pH}$ value. Though such a decrease is not statistically significant there might be some influence of applied vermicompost. After completion of the experiment, the organic carbon and B content of soil of vermicompost treated plots was found to be increased to some extent and these values are higher than those of the only mineral Zn-B treated plot as well as the control plot. Such higher content of organic carbon and B may be attributed to the applied vermicompost. Available P content showed a remarkable increase in post-harvest soils than the initial content. The highest content of $\mathrm{P}$ was observed in T1 (control) treatment while the lowest was found in T2 treatment (3 kg Zn ha-1 + 2 kg B ha-1) where Zn and B were supplied only through chemical fertilizer). This situation might be arisen because of the negative interaction between $\mathrm{P}$ and $\mathrm{Zn}$ in the soil-plant system; because all but control plots were treated with $\mathrm{Zn}$ through applying either mineral fertilizer only or with a combination of mineral fertilizer and vermicompost. The $\mathrm{Zn}$ content of the soil in all the treatments increased considerably except the control. It is because those plots were received Zn through fertilization.

\section{Conclusion}

Sole application of chemical fertilizers can supplement zinc-boron nutrition for cabbage production. But the application of vermicompost in combination with chemical fertilizers is better performing to supply required zinc and boron nutrition for quality production of cabbage. Such practice of vermicompost application might be helpful for retaining degraded soil health.

\section{Acknowledgements}

We gratefully acknowledge UGC (University Grants Commission) of Bangladesh for the fellowship and financial assistance provided in the way of accomplishing the concern research work. 


\section{References}

Abdelmonem, M.E.M., Kuttyammoo, M., Hassanein, K., Zayed, A.E.Z., 2016. Vermicomposting: analysis of soil nutrients enrichment with indigenous species from Jazan province of Saudi Arabia. International Journal of Advanced Research in Biological Sciences 3(10):131-137.

BARC, 2012. Fertilizer Recommendation Guide, Bangladesh Agricultural Research Council. Farmgate, Dhaka, Bangladesh. $274 p$.

BBS, 2017. Bangladesh Bureau of Statistics. Yearbook of Agricultural Statistics. Statistics and Informatics Division, Ministry of Planning, Government of the People's Republic of Bangladesh. Available at: [access date: 24.02.2020]: http://www.bbs.gov.bd/

Bray, R.H., Kurtz, L.T., 1945. Determination of total, organic and available forms of phosphorus in soils. Soil Science 59(1): 39-45.

Bremner, J.M., Mulvaney, C.S., 1982. Nitrogen total. In: Methods of soil analysis. Part 2 Chemical and microbiological properties. 2nd edition. Page, A.L., Miller, R.H., Keeney, D.R. (Eds.). American Society of Agronomy Inc., Madison, Wisconsin, USA. pp. 595-624.

Bukvic, G., Antunovic, M., Popović, S., Rastija, M., 2003. Effect of P and Zn fertilisation on biomass yield and its uptake by maize lines (Zea mays L.). Plant, Soil and Environment 49(11): 505-510.

Cakmak, I., Torun, B., Eronoglu, B., Ozturk, L., Marschner, H., Kalayci, M., Ekiz, H., Yilmaz, A., 1998. Morphological and physiological differences in the response of cereals to zinc deficiency. Euphytica 100: 349-357.

Chapman, H.D., Pratt, P.F., 1961. Methods of Analysis for Soil, Plant and Water. Division of Agricultural Sciences, University of California, USA.

Edwards, C.A., 1988. Breakdown of animal, vegetable and industrial organic wastes by earthworms. In: Earthworms in Waste and Environmental Management. Edwards C.A., Neuhauser, E.F. (Eds.). SPB, The Hague, Netherlands, pp. 21-31.

FAO and UNDP. 1988. Land resources appraisal of Bangladesh for agricultural development. Report 2. Agroecological Regions of Bangladesh. United Nations Development Programme and Food and Agriculture Organization. pp. 212221.

Fox, R.L., Olson, R.A., Rhoades, H.F., 1964. Evaluating the sulfur status of soils by plants and soil tests. Soil Science Society of America Journal 28(2): 243-246.

Gee, G.W., Bauder, J.W., 1986. Particle-size Analysis. In: Methods of Soil Analysis. Part 2, Chemical and Microbiological Properties. Page, A.L., Miller, R.H., Keeney, D.R. (Eds.), 2nd Edition. Agronomy Monograph No. 9, American Society of Agronomy, Soil Science Society of America. Madison, Wisconsin, USA. pp. 383-411.

Gomez, K.A., Gomez, A.A., 1984. Statistical procedures for agricultural research. John Wiley \& Sons. New York. USA.

Hu, D., Bell, R.W., Xie, Z., 1996. Zinc and phosphor responses in transplanted oilseed rape. Soil Science and Plant Nutrient 42(2): 333-344.

Islam, M.S., 2008. Soil fertility history, present status and future scenario in Bangladesh. Bangladesh Journal of Agriculture and Environment 4: 129-151.

Jadhav, A.D., Talashilkar, S.C., Pawar, A.G., 1997. Influence of the conjunctive use of FYM, vermicompost and urea on growth and nutrient uptake in rice. Journal of Maharashtra Agricultural Universities 22: 249-250.

Jones, L.H.P., Cowling, D.W., Lockyer, D.R., 1972. Plant-available and extractable sulphur in some soils of England and Wales. Soil Science 114(2): 104-114.

Kale, R.D., Mallesh, B.C., Bano, K., Bagyaray, D.J., 1992. Influence of vermicompost application on the available macronutrients and selected microbial populations in a paddy field. Soil Biology and Biochemistry 24(12): 13171320.

Keren, R., 1996. Boron. In: Methods of Soil Analysis, Part 3 - Chemical Methods. Sparks, D.L., Page, A.L., Helmke, P.A., Loeppert, R.H., Soltanpour, P.N., Tabatabai, M.A., Johnston, C.T., Sumner, M.E. (Eds.). American Society of Agronomy Inc., Madison, Wisconsin, USA. pp. 603-626.

Keren, R., Bingharn, F.T., 1985. Boron in water, soil, and plants. In: Advances in Soil Science. Steward, B.A. (Ed.). Volume 1, Springer-Verlag, New York, USA. pp.229-276.

Khattak, S.G., Rohullah, A., Malik, A., Perveen, Q., Ibrar, M., 2006. Assessing maize yield and quality as affected by Zn as soil or foliar applications. Sarhad Journal of Agriculture 22: 465-472.

Knudsen, D., Peterson, G.A., Pratt, P.F., 1982. Lithium, Sodium, and Potassium. In: Methods of soil analysis. Part 2 Chemical and microbiological properties. 2nd edition. Page, A.L., Miller, R.H., Keeney, D.R. (Eds.). American Society of Agronomy Inc., Madison, Wisconsin, USA. pp. 225-246.

Lindsay, W.L., Norvell, W.A., 1978. Development of a DTPA soil test for zinc, iron, manganese, and copper. Soil Science Society of America Journal 42(3): 421-428.

Lourduraj, A.C., Yadav, B.K., 2005. Effect of vermicompost application on soil and plant growth. In Verms and Vermitechnology. Kumar, A., (Ed.). A.P.H. Publishing Corp. New Delhi, pp. 81-96.

Makulec, G., 2002. The role of Lumbricus rubellus Hoffm. In determining biotic and abiotic properties of peat soils. Polish Journal of Ecology 50(3): 301-339.

Mandal, B., Ghosh, S., Chattopadhyay, A.P., 2004. Distribution of extractable boron content in acidic soils of West Bengal in relation to soil properties. Indian Journal of Agricultural Sciences 74(12): 658-662. 
Maqsood, M.A., Rahmatullah, Ranjha, A.M., Hussain, M., 2009. Differential growth response and zinc utilization efficiency of wheat genotype in cultivars buffered nutrient solution. Soil and Environment 28(2): 174-178.

Maret, W., Sandstead, H.H., 2006. Zinc requirements and the risks and benefits of zinc supplementation. Journal of Trace Elements in Medicine and Biology 20(1): 3-18.

McLean, E.O., 1982. Soil pH and Lime Requirement. In: Methods of soil analysis. Part 2 Chemical and microbiological properties. 2nd edition. Page, A.L., Miller, R.H., Keeney, D.R., (Eds.). American Society of Agronomy Inc., Madison, WI, USA. pp. 199-224.

Mousavi, S.R., 2011. Zinc in crop production and interaction with phosphorus. Australian Journal of Basic and Applied Sciences 5(9): 1503-1509.

Nelson, D.W., Sommers, L.E., 1996. Total Carbon, Organic Carbon, and Organic Matter. In: Methods of Soil Analysis, Part 3, Chemical Methods. Sparks, D.L., Page, A.L., Helmke, P.A., Loeppert, R.H., Soltanpour, P.N., Tabatabai, M.A., Johnston, C.T., Sumner, M.E. (Eds.). American Society of Agronomy Inc., Madison, Wisconsin, USA. pp. 961-1010.

Olsen, S.R., Sommers, L.E., 1982. Phosphorus. In: Methods of soil analysis. Part 2 Chemical and microbiological properties. 2nd edition. Page, A.L., Miller, R.H., Keeney, D.R., (Eds.). American Society of Agronomy Inc., Madison, WI, USA. pp. 403-430.

Piper, C.S., 1950. Soil and Plant Analysis. Adelaide University Hassel press. Australia.

Prabakaran, J., 2005. Biomass resources in vermicomposting. In Proceedings of the State Level Symposium on Vermicomposting Techonolgy for Rural Development. Jayakumar, E., (Ed.). Madurai, Tamil Nadu, India, pp. 27-40.

Rajendran, M., Thivyatharsan, R., 2014. Performance of different species of earthworms on vermicomposting. International Journal of Research in Agriculture and Food Sciences 2(3):1-6.

Reisenauer, H.M., Walsh, L.M., Hoeft, R.G., 1973. Testing soils for sulphur, boron, molybdenum and chlorine. In Soil testing and plant analysis. Walsh, L.M., Beaton, J.D., (Eds.) SSSA, Madison, WI, pp. 73-200.

Rijpma, J., Jahiruddin, M., 2004. Strategy and plan for use of soil nutrient balance in Bangladesh. Final report of shortterm assignment, SFFP/DANIDA.

Shi-wei, Z., Fu-zhen, H., 1991. The nitrogen uptake efficiency from $15 \mathrm{~N}$ labeled chemical fertilizer in the presence of earthworm manure (cast). In: Advances in Management and Conservation of Soil Fauna. Veeresh, G.K., Rajagopal, D., Viraktamath, C.A., (Eds.). Oxford and IBH Publishing Co., New Delhi, India. pp. 539-542.

Shorrocks, V.M., 1997. The occurrence and correction of boron deficiency. Plant and Soil 193:121-148.

Singh, A., Singh, R.V., Saxena, A.K., Shivay, Y.S., Nain, L., 2014. Comparative studies on composting efficiency of Eisenia fetida (Savigny) and Perionyx excavates (Perrier). Journal of Experimental Biology and Agricultural Sciences 2(5):508-517.

Sinha, R.K., Heart, S., Bharambe, G., Patil, S., Bapat, P.D., Chauhan, K., Valani, D., 2009. Vermiculture Biotechnology: The emerging cost-effective and sustainable technology of the 21st century for multiple uses from waste and land management to safe and sustained food production. Environmental Research Journal 3(1):41-110.

Sreenivas, C., Muralidhar, S., Rao, M.S., 2000. Vermicompost, a viable component of IPNSS in nitrogen nutrition of ridge gourd. Annals of Agricultural Research 21(1): 108-113.

Suthar, S., 2007. Nutrient changes and biodynamics of epigeic earthworm Perionyx excavatus (Perrier) during recycling of some agriculture wastes. Bioresource Technology 98(8): 1608-1614.

Tabatabai, M.A., 1996. Sulphur. In: Methods of Soil Analysis, Part 3 - Chemical Methods. Sparks, D.L., Page, A.L., Helmke, P.A., Loeppert, R.H., Soltanpour, P.N., Tabatabai, M.A., Johnston, C.T., Sumner, M.E. (Eds.). American Society of Agronomy Inc., Madison, Wisconsin, USA. pp. 921-960.

Theunissen, J., Ndakidemi, P.A., Laubscher, C.P., 2010. Potential of vermicompost produced from plant waste on the growth and nutrient status in vegetable production. International Journal of the Physical Sciences 5(13): 19641973.

Webb, M.J., Loneagan, J.F., 1988. Effect of zinc deficiency on growth, phosphorus concentration and phosphorus toxicity of wheat plants. Soil Science Society of America Journal 52(6): 1676-1680.

Yadav, A., Garg, V.K., 2011. Recycling of organic wastes by employing Eisenia fetida. Bioresource Technology 102(3): 28742880.

Yilmaz, A., Ekiz, H., Torun, B., Gultekin, I., Karanalik, S., Bagsi, S.A., Cakmak, I., 1997. Effect of different zinc application methods on grain yield and zinc concentration in wheat cultivars grown on zinc-deficient calcareous soils. Journal of Plant Nutrition 20(4-5):461-471.

Yoshida, S., Forno, A.D., Cock, J.A., Gomez, K.A., 1976. Physiological Studies of Rice. 2nd Ed. International Rice Research Institute, Manila, Philippines. 